\title{
Overwintering sites of the predacious mite Neoseiulus californicus (McGregor) (Acari: Phytoseiidae) in satsuma mandarin orchards on Jeju Island, Korea
}

\author{
Mitsuhiro KaWASHIMA* and Chuleui JUNG* \\ School of Bioresource Sciences, Andong National University; Andong 760-749, Republic of Korea
}

(Received 21 August 2009; Accepted 19 October 2009)

\begin{abstract}
We investigated the overwintering sites of the predacious mite Neoseiulus californicus in two satsuma mandarin orchards on Jeju Island, Korea, in February 2008. Our objectives were to improve the biological control strategy with $N$. californicus in perennial crops and to develop effective methods for examining the overwintering situations of N. californicus in the field. Nearly all specimens of $N$. californicus collected in the orchards were adult females, and the numbers of adult males and juveniles were very low. Most $N$. californicus were collected on herbaceous plants on the ground rather than on satsuma mandarin trees or woody plants surrounding the orchards. Among herbaceous plant species, higher densities of $N$. californicus were consistently found on species with rosette-type leaves compared to those with non-rosette-type leaves. Our results suggest that rosette-forming herbaceous plants are effective overwintering sites for conserving N. californicus in orchards. Furthermore, these plants would also provide useful sites for examining the potential overwintering situations of $N$. californicus in the field.
\end{abstract}

Key words: Habitat management; herbaceous weed; natural enemy; rosette-forming plant; winter

\section{INTRODUCTION}

Phytoseiid mites include several important predacious biological control agents of phytophagous mites (e.g., Tetranychoidea, Eriophyoidea, and Tarsonemidae) and other small arthropod pests (e.g., thrips and whiteflies) of many plant species (Nomikou et al., 2002; Gerson et al., 2003). Neoseiulus californicus (McGregor) is globally distributed in both arid and humid areas throughout Europe, Africa, North and South America, and Asia (de Moraes et al., 2004; Pringle and Heunis, 2006); the species is also commercially available in many countries. This mite is typically used to control spider mites in the field and in protected crops (Castagnoli and Simoni, 2003) and can also feed on other food items, such as tarsonemid mites and even plant pollen, to fuel its development and reproduction (Castagnoli and Falchini, 1993; Castagnoli et al., 1999).

In Korea, the occurrence of $N$. californicus in the field was first reported in citrus orchards on Jeju Island in the southernmost region of Korea (Jung et al., 2006); however, no natural occurrences of $N$. californicus have been documented on mainland Korea until now, despite several faunal surveys of phytoseiid mites in non- and agricultural fields (Ryu et al., 1997, 2001; Jung et al., 2003; Jung and Lee, 2004; Kawashima et al., 2008) as well as taxonomical studies of Phytoseiidae (Ryu, 1993, 2007) in Korea. On the other hand, the commercial production of indigenous Jeju Island strains of N. californicus began in 2006; therefore, farmers can currently use these commercial mites to control spider mites on mainland Korea whenever necessary.

Winter is a crucial season for the survival of arthropods, especially in temperate regions. Winter temperatures affect the winter survival of arthropod species (Kiritani, 2006) and may be an important factor determining their geographic distribution (Tougou et al., 2009). In agricultural fields, the successful overwintering of natural enemies allows their early season colonization on perennial crops, often resulting in effective pest suppression (Landis et al., 2000). Phytoseiid mites overwinter on trees, on the ground, or both (Veerman, 1992;

\footnotetext{
* To whom correspondence should be addressed at: E-mail: mitsuhirokawashima@yahoo.co.jp; cjung@andong.ac.kr
} DOI: $10.1303 /$ aez.2010.191 
Nyrop et al., 1994), depending on species-specific characteristics. In southeast France, $N$. californicus reportedly climbs apple trees from the ground early in the season (Raworth et al., 1994); however, additional data regarding the overwintering sites of $N$. californicus are quite scarce.

In the present study, we surveyed two satsuma mandarin orchards on Jeju Island to determine the overwintering sites of $N$. californicus in the field. This information will be useful for two main reasons. First, the conservation of preferred overwintering sites of $N$. californicus may help to advance biological control strategies in citrus orchards on Jeju Island, where $N$. californicus serves as an effective biological control agent of the citrus red mite Panonychus citri (McGregor), one of the most important pests of citrus trees in Korea. Second, clarifying overwintering sites may also be useful for examining the potential overwintering situation of $N$. californicus on mainland Korea, as it is currently unknown whether this species can overwinter on the mainland.

\section{MATERIALS AND METHODS}

In (South) Korea, more than 99\% of satsuma mandarin trees, Citrus unshiu S.Marcov., are cultivated on Jeju Island (the Korean Statistical Information Service, http://www.kosis.kr/; data from 2000 to 2006 and from 2008 to 2009). We surveyed two conventionally managed satsuma mandarin orchards on Jeju Island: orchard A $\left(33^{\circ} 20^{\prime} \mathrm{N}\right.$, $126^{\circ} 15^{\prime} \mathrm{E}, 113 \mathrm{~m}$ altitude) in Jeoji-ri, Hangyeongmyeon, Jeju-si, Jeju-do, Korea, and orchard B $\left(33^{\circ} 16^{\prime} \mathrm{N}, 126^{\circ} 37^{\prime} \mathrm{E}, 77 \mathrm{~m}\right.$ altitude) in Sillye-ri, Namwon-eup, Seogwipo-si, Jeju-do, Korea (Fig.
1). In both orchards, agrochemicals were conventionally sprayed to control disease and pest arthropods from spring to autumn. According to periodical leaf observations (three times a month) of satsuma mandarin trees from April to October 2007, P. citri and N. californicus occurred as a predominant species of spider mites and phytoseiid mites, respectively, in both orchards (K.S. Choi, unpublished data).

Meteorological data from Jeju Island were obtained via the website of the Korea Meteorological Administration (http://www.kma.go.kr/). The coldest period from late 2007 to early 2008 on the island was from January to February (Fig. 2). Average, maximum, and minimum air temperatures in January 2008 were $6.4 \pm 0.52^{\circ} \mathrm{C}( \pm \mathrm{SE}), 18.3^{\circ} \mathrm{C}$, and $0.2^{\circ} \mathrm{C}$, respectively; those in February 2008 were $5.1 \pm 0.39^{\circ} \mathrm{C}( \pm \mathrm{SE}), 14.8^{\circ} \mathrm{C}$, and $-0.5^{\circ} \mathrm{C}$. Minimum air temperatures were above freezing on all dates in January and February 2008, except for one day in February. Similar meteorological conditions probably occurred in the two study orchards.

The overwintering sites of $N$. californicus were surveyed in the orchards on 2 and 28 February 2008. Various plant species occur in orchards: satsuma mandarin trees, herbaceous plant species on the ground, and woody plant species surrounding the orchards as windbreaks. Parts of the major plant species of each type were collected as potential overwintering sites of $N$. californicus. Although we collected only living plants for the survey, on the ground there is also the possibility that $N$. californicus overwinters under litter, in soil, and so on (ref. Veerman, 1992). In the present study, however, we assumed living herbaceous plants as a representative of potential overwintering sites of $N$. califor-
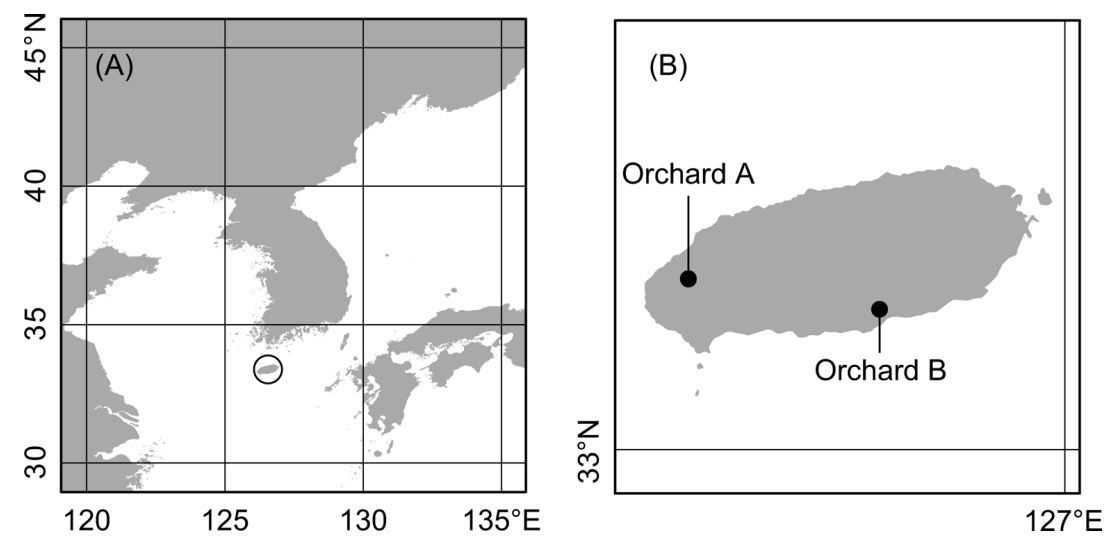

Fig. 1. Jeju Island (open circle) (A) and the two satsuma mandarin orchards on Jeju Island used in the study (B). 


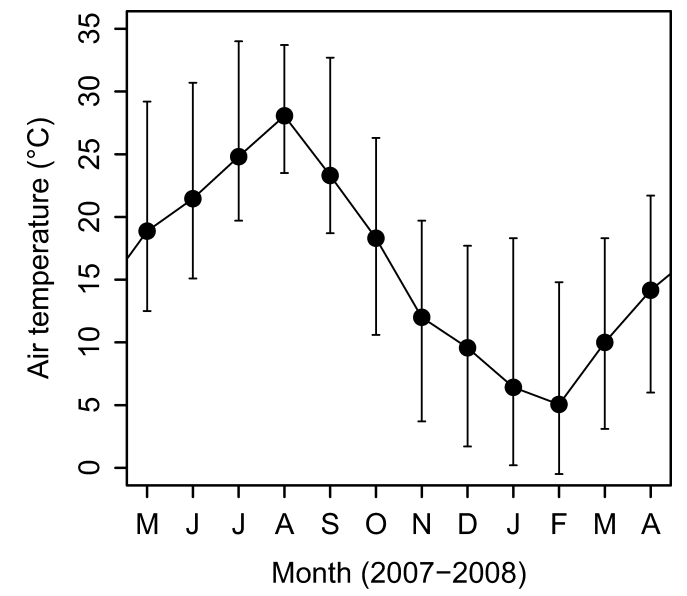

Fig. 2. Seasonal changes in the monthly air temperature on Jeju Island from May 2007 to April 2008. Black circles indicate monthly mean air temperatures, and vertical bars indicate the range between monthly maximum and minimum air temperatures. Data were modified from data obtained from the Korea Meteorological Administration (http://www.kma.go.kr/). nicus on the ground for the following reasons. First, the number of phytoseiid mites overwintering on the ground was considered to be highly affected by the surface structure and/or food conditions on the ground. Second, plant structures of living herbaceous plants are diversified among species. Finally, these plants are also hosts of various prey items of $N$. californicus.

Detailed information on plants collected in both orchards, including species name, sample unit, and sample dry weight, is presented in Tables 1 and 2 . We collected leaves and twigs from satsuma mandarin trees. On 2 February, leaves and/or twigs (ca. $10 \mathrm{~cm}$ ) with leaves plus a pedicel were randomly collected in the orchards. On 28 February, twigs (ca. $10 \mathrm{~cm}$ ) with leaves plus a pedicel were randomly collected, and then separated into leaves and twigs with a pedicel using scissors. Although bark crevices and loose bark are reported as suitable overwintering sites of several phytoseiid species

Table 1. Sample information for plants and phytoseiid mites collected from plants in two satsuma mandarin orchards on 2 February 2008

\begin{tabular}{|c|c|c|c|c|c|c|}
\hline \multirow{2}{*}{ Orchard } & \multirow{2}{*}{ Family name } & \multirow{2}{*}{ Species name } & \multirow{2}{*}{ Sample unit } & \multirow{2}{*}{$\begin{array}{c}\text { Dry } \\
\text { weight } \\
(\mathrm{g})^{\mathrm{a}}\end{array}$} & \multicolumn{2}{|c|}{$\begin{array}{l}\text { Total phytoseiids } \\
\text { collected }^{\text {b }}\end{array}$} \\
\hline & & & & & $\begin{array}{c}N . \\
\text { californicus }\end{array}$ & $\begin{array}{l}\text { Other } \\
\text { spp. }\end{array}$ \\
\hline \multirow[t]{7}{*}{ A } & Rutaceae & Citrus unshiu S.Marcov. $^{\mathrm{c}}$ & Leaf & 626 & 0 & 0 \\
\hline & Rutaceae & Citrus unshiu S.Marcov. & Twig with leaves and a pedicel & 466 & 1 & 0 \\
\hline & Asteraceae & Youngia japonica (L.) DC. ${ }^{\mathrm{d}}$ & Above-ground part & 218 & 11 & 1 \\
\hline & Lamiaceae & Lamium amplexicaule L. $^{\mathrm{d}}$ & Above-ground part & 207 & 3 & 0 \\
\hline & Caryophyllaceae & Stellaria media (L.) Vill. ${ }^{\mathrm{d}}$ & Above-ground part & 436 & 0 & 1 \\
\hline & Taxodiaceae & Cryptomeria japonica (L.f.) D.Don ${ }^{\mathrm{e}}$ & Twig with leaves & 415 & 0 & 0 \\
\hline & Cupressaceae & Thuja orientalis $\mathrm{L} . \mathrm{e}^{\mathrm{e}}$ & Twig with leaves & 1,117 & 0 & 1 \\
\hline \multirow[t]{4}{*}{ B } & Rutaceae & Citrus unshiu S.Marcov. ${ }^{\mathrm{c}}$ & Twig with leaves and a pedicel & 540 & $2^{f}$ & 0 \\
\hline & Asteraceae & Youngia japonica (L.) DC. ${ }^{\mathrm{d}}$ & Above-ground part & 31 & 10 & 0 \\
\hline & Lamiaceae & Lamium amplexicaule L. $^{\mathrm{d}}$ & Above-ground part & 25 & 4 & 0 \\
\hline & Caryophyllaceae & Stellaria media (L.) Vill. ${ }^{\mathrm{d}}$ & Above-ground part & 39 & $3^{\mathrm{g}}$ & 0 \\
\hline
\end{tabular}

\footnotetext{
${ }^{a}$ Dry weight was measured to the nearest $1 \mathrm{~g}$.

${ }^{\mathrm{b}}$ All motile stages.

${ }^{\mathrm{c}}$ Satsuma mandarin trees.

${ }^{\mathrm{d}}$ Herbaceous plants on the ground.

${ }^{\mathrm{e}}$ Woody plants surrounding the orchards.

${ }^{\mathrm{f}}$ One nymph was included.

${ }^{\mathrm{g}}$ One larva was included.

All collected phytoseiid mites were adult females, with the exception of the individuals noted above.

Underlined names indicate herbaceous plant species with rosette-type leaves on the collection date.
} 
Table 2. Sample information for plants and phytoseiid mites collected from plants in two satsuma mandarin orchards on 28 February 2008

\begin{tabular}{|c|c|c|c|c|c|c|}
\hline \multirow{2}{*}{ Orchard } & \multirow{2}{*}{ Family name } & \multirow{2}{*}{ Species name } & \multirow{2}{*}{ Sample unit } & \multirow{2}{*}{$\begin{array}{c}\text { Dry } \\
\begin{array}{c}\text { weight } \\
(\mathrm{g})^{\mathrm{a}}\end{array}\end{array}$} & \multicolumn{2}{|c|}{$\begin{array}{l}\text { Total phytoseiids } \\
\text { collected }^{\mathrm{b}}\end{array}$} \\
\hline & & & & & $\begin{array}{l}N . \\
\text { californicus }\end{array}$ & $\begin{array}{l}\text { Other } \\
\text { spp. }\end{array}$ \\
\hline \multirow[t]{11}{*}{ A } & Rutaceae & Citrus unshiu S.Marcov. ${ }^{\mathrm{c}}$ & Leaf & 440 & 0 & 0 \\
\hline & Rutaceae & Citrus unshiu S.Marcov. ${ }^{\mathrm{c}}$ & Twig with a pedicel & 140 & 0 & 0 \\
\hline & Asteraceae & $\underline{\text { Conyza sumatrensis E.Walker }}^{\mathrm{d}}$ & Above-ground part & 10 & 1 & 0 \\
\hline & Asteraceae & Youngia japonica (L.) DC. & Above-ground part & 240 & 11 & 0 \\
\hline & Rubiaceae & $\begin{array}{l}\text { Galium spurium var. echinospermon } \\
\text { (Wallr.) Hayek }{ }^{\mathrm{d}}\end{array}$ & Above-ground part & 30 & 1 & 0 \\
\hline & Lamiaceae & Lamium amplexicaule L. $^{\mathrm{d}}$ & Above-ground part & 160 & 4 & 0 \\
\hline & Caryophyllaceae & Stellaria media (L.) Vill. ${ }^{\mathrm{d}}$ & Above-ground part & 500 & 2 & 2 \\
\hline & Taxodiaceae & Cryptomeria japonica (L.f.) D.Don ${ }^{\mathrm{e}}$ & Twig with leaves & 130 & 0 & 0 \\
\hline & Taxodiaceae & Cryptomeria japonica (L.f.) D.Don ${ }^{\mathrm{e}}$ & Bark & 1,200 & 0 & 1 \\
\hline & Cupressaceae & Thuja orientalis L. ${ }^{\mathrm{e}}$ & Twig with leaves & 400 & 0 & 0 \\
\hline & Cupressaceae & Thuja orientalis L. ${ }^{\mathrm{e}}$ & Bark & 700 & 0 & 2 \\
\hline \multirow[t]{10}{*}{$\mathrm{B}$} & Rutaceae & Citrus unshiu S.Marcov. ${ }^{\mathrm{c}}$ & Leaf & 460 & 0 & 0 \\
\hline & Rutaceae & Citrus unshiu S.Marcov. ${ }^{\mathrm{c}}$ & Twig with a pedicel & 210 & 0 & 0 \\
\hline & Asteraceae & Conyza sumatrensis E.Walker ${ }^{\mathrm{d}}$ & Above-ground part & 60 & 27 & 0 \\
\hline & Asteraceae & Gnaphalium purpureum $\mathrm{L}^{\mathrm{d}}$ & Above-ground part & 80 & $16^{\mathrm{f}}$ & 0 \\
\hline & Asteraceae & Youngia japonica (L.) DC. $^{\text {d }}$ & Above-ground part & 380 & $109^{\mathrm{g}}$ & 2 \\
\hline & Rubiaceae & $\begin{array}{l}\text { Galium spurium var. echinospermon } \\
\text { (Wallr.) Hayek }{ }^{\mathrm{d}}\end{array}$ & Above-ground part & 20 & 1 & 0 \\
\hline & Lamiaceae & Lamium amplexicaule $\mathrm{L}^{\mathrm{d}}$ & Above-ground part & 220 & 10 & 1 \\
\hline & Caryophyllaceae & Stellaria media (L.) Vill. ${ }^{\mathrm{d}}$ & Above-ground part & 290 & 34 & 0 \\
\hline & Taxodiaceae & Cryptomeria japonica (L.f.) D.Don ${ }^{\mathrm{e}}$ & Twig with leaves & 300 & 0 & 0 \\
\hline & Taxodiaceae & Cryptomeria japonica (L.f.) D.Don ${ }^{\mathrm{e}}$ & Bark & 1,030 & 0 & 0 \\
\hline
\end{tabular}

\footnotetext{
${ }^{a}$ Dry weight was measured to the nearest $10 \mathrm{~g}$.

${ }^{\mathrm{b}}$ All motile stages.

${ }^{\mathrm{c}}$ Satsuma mandarin trees.

${ }^{\mathrm{d}}$ Herbaceous plants on the ground.

${ }^{\mathrm{e}}$ Woody plants surrounding the orchards.

${ }^{\mathrm{f}}$ One adult male was included.

${ }^{\mathrm{g}}$ Three adult males and one nymph were included.

All collected phytoseiid mites were adult females, with the exception of the individuals noted above.

Underlined names indicate herbaceous plant species with rosette-type leaves on the collection date.
}

(Leetham and Jorgensen, 1969), we did not collect bark samples from satsuma mandarin trees since tree bark was hard and smooth, not loose. For herbaceous plant species, we defined the aboveground part (i.e., shoot) of each plant as a sample unit, and randomly collected samples of each species in the orchards. Thus, when collecting samples, we collected all shoot parts of each plant, not parts of shoots, and roots were cut using scissors.
From woody plant species surrounding the orchards, twigs with leaves and loose bark were randomly collected in the orchards. Although we did not count the number of each sample unit collected (e.g., no. of leaves and shoots), we measured the dry weight of each sample. Although plants were collected twice, more diverse and larger numbers of samples were collected on 28 February. As far as possible, sufficient amounts of each sample were 
collected within the collection period (ca. 1-2 h per orchard) by four people on 28 February.

Plant samples were sealed in reclosable plastic bags and transported to the laboratory at Andong National University $\left(36^{\circ} 32^{\prime} \mathrm{N}, 128^{\circ} 47^{\prime} \mathrm{E}\right)$. Samples were placed in Tullgren funnels under 30 -W light bulbs for 5 days. Mites were extracted into vials containing $70 \%$ ethanol, which were secured to the bottom of the Tullgren funnels, and vial contents were observed under a binocular microscope. All phytoseiid mites were mounted in PVA medium (BioQuip Products, CA, USA) on slides for species identification. After funnel extraction, the dry weight of each plant sample was measured.

All plants were identified to the species level. Since some plants were somewhat difficult to identify from only winter samples, both orchards were visited again on 2 July 2009 to confirm species identities. Plant species nomenclature followed the Korean Plant Names Index (http://www. nature.go.kr/kpni/).

\section{RESULTS}

The density of phytoseiid mites was higher in orchard B than in orchard A (Tables 1 and 2). Neoseiulus californicus was collected on plants in both satsuma mandarin orchards and accounted for $91.9 \%$ and $96.4 \%$ of the total number of phytoseiid mites collected on 2 and 28 February, respectively (Tables 1 and 2). Three, 31, and no individuals of $N$. californicus were collected from satsuma mandarin trees, herbaceous plants, and surrounding woody plants, respectively, in the two orchards on 2 February (Table 1). On 28 February, this mite was only collected from herbaceous plants (216 individuals) and was not found on satsuma mandarin trees or surrounding woody plants in either orchard (Table 2). The vast majority (97.2\%) of N. californicus collected in both orchards on the two collection dates were adult females (Tables 1 and 2). Very few adult male or nymphal/larval stages of mites were collected (seven individuals) (Tables 1 and 2).

Herbivorous tetranychoid mites, an important prey-item group of $N$. californicus, were also collected from the two orchards. The major groups included Bryobiini, Panonychus, and Tuckerellidae; one individual of Tenuipalpidae was collected (Table 3); however, none of these mite groups exhibited strong relationships with herbaceous plants on the ground in the orchards during winter. Mites of Bryobiini and Tuckerellidae were more frequently collected on woody plants surrounding the orchards than on herbaceous plants, and none was collected from satsuma mandarin trees (Table 3). In contrast, Panonychus mites were more frequently collected from satsuma mandarin trees than herbaceous plants, and only one Panonychus individual was collected from woody plants surrounding the orchards (Table 3). Although we did not identify all Panonychus mites, most appeared to be P. citri, one of the most important pests of citrus trees.

The number of $N$. californicus collected from herbaceous plants was not positively correlated significantly to the amount (dry weight) of plants collected (one-tailed Spearman's rank correlation, 28 February: orchard A, $\rho=0.669, p=0.109$; orchard $\mathrm{B}, \rho=0.771, p=0.051,2$ February: no test due to small sample size). To compare the densities of $N$.

Table 3. Total numbers of mites belonging to Tetranychoidea collected in two satsuma mandarin orchards on the two collection dates in February 2008

\begin{tabular}{|c|c|c|c|c|c|c|}
\hline \multirow{2}{*}{ Plant } & \multicolumn{2}{|c|}{ Dry weight of plant samples (g) } & \multicolumn{4}{|c|}{ Total tetranychoids collected ${ }^{\mathrm{a}}$} \\
\hline & 2 Feb. $^{\mathrm{b}}$ & $28 \mathrm{Feb}^{\mathrm{c}}$ & Bryobiini & Panonychus & Tenuipalpidae & Tuckerellidae \\
\hline Satsuma mandarin trees & 1,632 & 1,250 & 0 & 222 & 0 & 0 \\
\hline Herbaceous plants & 956 & 1,990 & 33 & 24 & 1 & 5 \\
\hline Surrounding woody plants & 1,532 & 3,760 & $263^{\mathrm{d}}$ & 1 & 0 & 117 \\
\hline
\end{tabular}

\footnotetext{
${ }^{\text {a }}$ All motile stages.

${ }^{\mathrm{b}}$ Dry weight was measured to the nearest $1 \mathrm{~g}$.

${ }^{\mathrm{c}}$ Dry weight was measured to the nearest $10 \mathrm{~g}$.

${ }^{\mathrm{d}}$ Mites of Bryobiini were collected only from bark samples.

See Tables 1 and 2 for detailed sample information on the plants.
} 

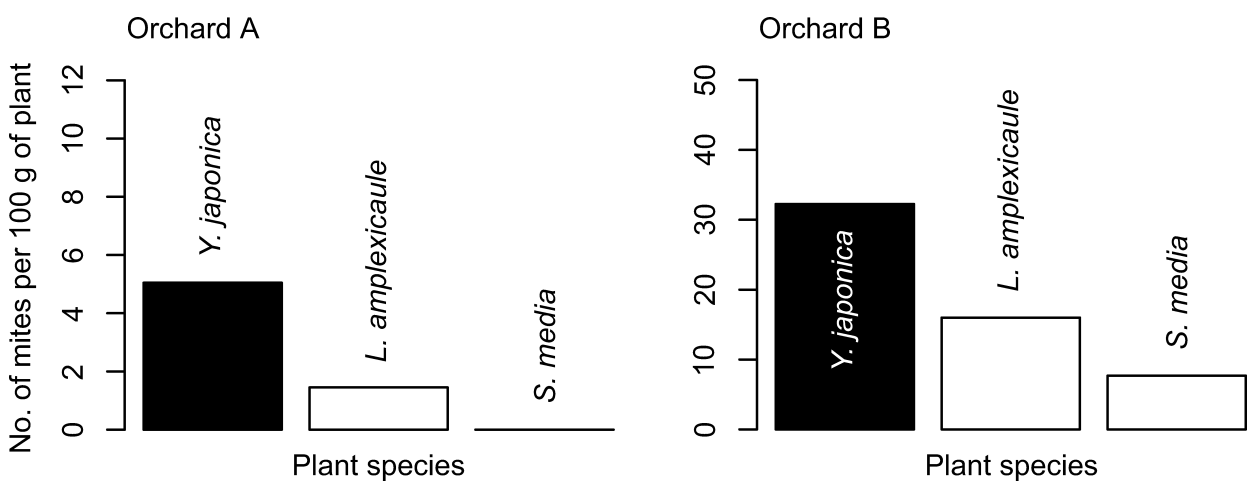

Fig. 3. Number of Neoseiulus californicus per $100 \mathrm{~g}$ dry weight of each herbaceous plant species collected on the ground of two satsuma mandarin orchards on 2 February 2008. Black bars indicate plant species with rosette-type leaves, and white bars indicate plant species with non-rosette-type leaves.
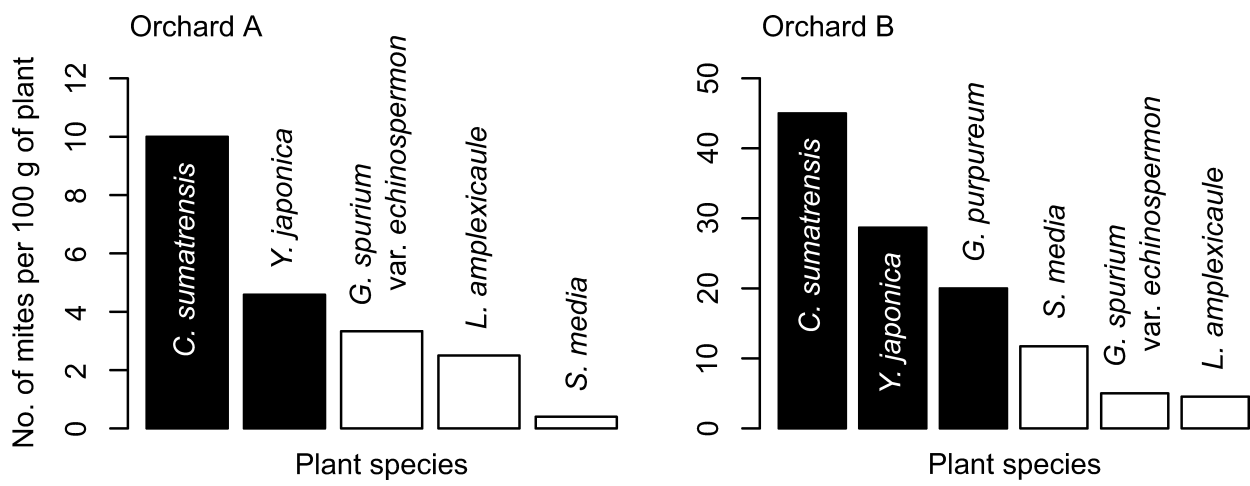

Fig. 4. Number of Neoseiulus californicus per $100 \mathrm{~g}$ dry weight of each herbaceous plant species collected on the ground of two satsuma mandarin orchards on 28 February 2008. Black bars indicate plant species with rosette-type leaves, and white bars indicate plant species with non-rosette-type leaves.

californicus among herbaceous plant species, we calculated the number of $N$. californicus collected per $100 \mathrm{~g}$ dry weight of each herbaceous plant species in each orchard on each collection date. The results indicated that a higher density of $N$. californicus was always found on three herbaceous plant species, Conyza sumatrensis E.Walker, Gnaphalium purpureum L., and Youngia japonica (L.) DC., compared to the other three species, Galium spurium var. echinospermon (Wallr.) Hayek, Lamium amplexicaule L., and Stellaria media (L.) Vill. (Figs. 3 and 4). On both collection dates, the former three species consisted of rosette-type leaves, whereas the latter three species had nonrosette-type leaves (Figs. 3 and 4).

\section{DISCUSSION}

In the present study, most of the phytoseiid mites collected in the two satsuma mandarin orchards were $N$. californicus. This species is also the dominant phytoseiid species in conventionally managed citrus orchards in Shizuoka Prefecture, Ehime Prefecture, and the Kyushu District in central to southwestern Japan, and serves as an effective predator of the dominant spider mite species, $P$. citri, on citrus trees (Katayama et al., 2006; Ohnishi et al., 2006; Kishimoto et al., 2007). Therefore, conservation of this species for the biological control of $P$. citri in citrus orchards will likely be quite beneficial; however, little is known about the overwintering behavior of this species in the field (e.g., Hart et al., 2002, for winter mortality), although several physiological studies have examined its winter hardiness (e.g., diapause propensity and cold tolerance; Castagnoli et al., 1996; Jolly, 2000; Hart et al., 2002; Gotoh et al., 2005).

Most of the $N$. californicus collected in the two orchards were adult females. Fertilized adult Phytoseiid mite females with the ability to diapause 
exhibit reproductive arrest; males and juveniles that fail to reach the overwintering stage before the onset of adverse climate conditions are likely to perish (Veerman, 1992). Strains of N. californicus vary in their propensity to diapause: e.g., $0 \%$ of two US strains and the Japanese strain (Jolly, 2000; Hart et al., 2002; Gotoh et al., 2005), 16\% of the Spanish strain (Jolly, 2000), 95\% of the UK strain (Jolly, 2000), and $84-100 \%$ of the Italian strain (Castagnoli et al., 1996) have been shown to enter diapause. Despite their small numbers, we collected males and juveniles of $N$. californicus, suggesting that the Jeju Island strain does not enter diapause. In a laboratory study of the diapause propensity of the Jeju strain of $N$. californicus, diapause could not be induced (Taj and Jung, unpublished data). Nevertheless, our results strongly suggest that the main overwintering stage of N. californicus in citrus orchards on Jeju Island is the adult female.

Our results indicate that $N$. californicus may prefer the ground for overwintering in orchards. These findings are further supported by a field study in apple orchards of southern France that suggested that this species climbed apple trees from the ground early in the season and searched for prey not only in trees but also in ground cover from the end of February to the middle of November (Raworth et al., 1994). Together with our results, these data imply that $N$. californicus does not constantly stay on trees but rather migrates between trees and the ground during the growing season. Furthermore, in our winter study, Panonychus mites, which are a suitable prey group for $N$. californicus, were more frequently collected on satsuma mandarin trees than on herbaceous plants on the ground, whereas $N$. californicus inhabited the ground. Due to this uncoupling of predator and prey during winter, the early migration of substantial numbers of $N$. californicus to trees would require careful management of ground habitats as well as the conservation of $N$. californicus populations in the early season (e.g., by avoiding hazardous pesticide treatments).

We consistently observed higher densities of $N$. californicus associated with herbaceous plant species with rosette-type leaves than with those exhibiting non-rosette-type leaves. More specifically, higher densities of the mite were found on $C$. sumatrensis, G. purpureum, and Y. japonica com- pared to G. spurium var. echinospermon, L. amplexicaule, and $S$. media. The former three species have rosette leaves constructed of broad leaves that lie near the soil on a stem with short internodes during winter, whereas the latter three species have non-rosette leaves constructed of small leaves on a stem with long internodes throughout the year. Although we did not examine on which parts of the rosette-forming plants this species overwintered, two possibilities were speculated. First, cover structures near the ground, such as between broad leaves of rosette-forming herbaceous plants and between those leaves and the ground, may provide suitable climatic conditions for phytoseiid mites by moderating temperature (Dabney et al., 2001) and humidity conditions, and/or protecting from UV radiation. Recently, Ohtsuka and Osakabe (2009) demonstrated that UV-B irradiation caused lethal damage to the eggs of the predacious phytoseiid mite Neoseiulus womersleyi (Schicha) in a laboratory experiment. Furthermore, the base of plants with dense leafstalks, such as stems with dense leafstalks of short internodes in rosette-forming herbaceous plants, may also be suitable overwintering sites for phytoseiid mites, and by hiding in such a structure the mites could reduce their winter mortality. If this assumption is correct, non-rosetteforming herbaceous plants with a similar structure at the base of plants, such as tillering gramineous plants, might also be suitable for overwintering phytoseiid mites. Rosette-forming plants exhibited patchy distributions and were not the dominant species on the ground in either study orchard; instead, non-rosette-forming plants, e.g., L. amplexicaule and $S$. media, dominated the orchards (Kawashima, personal observation); however, our results suggest that rosette-forming plants are effective overwintering sites for the conservation of $N$. californicus in orchards. Future studies should more thoroughly examine the function of rosetteforming plants in maintaining overwintering phytoseiid mites on the ground in perennial crop systems.

There is also the possibility that $N$. californicus overwinters in locations other than living plants, such as under litter and in soil, although we did not examine these locations in the present study. In Oregon, USA, Morris et al. (1996) showed that the addition of organic debris to peppermint fields increased the overwintering survival of Neoseiulus 
fallacis (Garman) compared to undisturbed natural conditions, whereas the removal of debris decreased survival.

Our results also have important implications for investigations of possible overwintering by $N$. californicus on mainland Korea, where natural occurrences of this species have not yet been confirmed. This species is at present distributed throughout Japan, except northern areas (Ehara and Gotoh, 2009), dominating some citrus, apple, and peach orchards (Mochizuki et al., 2005; Katayama et al., 2006; Ohnishi et al., 2006; Kishimoto et al., 2007). The region where $N$. californicus is distributed in Japan partially overlaps in latitude with the fruitgrowing areas of mainland Korea; therefore, there is a possibility that $N$. californicus can overwinter on mainland Korea. Ground habitats, such as rosette-forming herbaceous plants, would be useful for examining the potential overwintering situation of this species in the field.

\section{ACKNOWLEDGMENTS}

We thank the local farmers for permission to use their orchards. We also thank Kyung San Choi of the National Institute of Subtropical Agriculture for assisting with field work and providing helpful information on the orchards. We are also grateful to members of the Insect Ecology Laboratory of ANU for assisting with field work, and Myung Soon Park of the Plant Taxonomy Laboratory of ANU for helping with the identification of plant species. This study was supported in part by funds from the Agricultural R \& D Promotion Center (project no. 107039-03) and a Korea Research Foundation Grant (KRF-2007-210-F00001) from the Ministry of Education and Human Resources Development, Republic of Korea.

\section{REFERENCES}

Castagnoli, M. and L. Falchini (1993) Suitability of Polyphagotarsonemus latus (Banks) (Acari Tarsonemidae) as prey for Amblyseius californicus (McGregor) (Acari Phytoseiidae). Redia 76: 273-279.

Castagnoli, M. and S. Simoni (2003) Neoseiulus californicus (McGregor) (Acari Phytoseiidae): survey of biological and behavioural traits of a versatile predator. Redia 86 : 153-164.

Castagnoli, M., M. Liguori, S. Simoni, M. Pintucci, S. Guidi and L. Falchini (1996) Observations on diapause induction in three phytoseiid (Phytoseiidae) species. In Acarology IX. Vol. 1. Proceedings (R. Michell, D. J. Horn, G. R. Needham and W. C. Welbourn, eds.). Ohio Biological Survey, Columbus, pp. 9-12.

Castagnoli, M., S. Simoni and N. Biliotti (1999) Mass-rearing of Amblyseius californicus (Acari: Phytoseiidae) on two alternative food sources. In Ecology and Evolution of the Acari (J. Bruin, L. P. S. van der Geest and M. W. Sabelis, eds.). Kluwer Academic Publishers, Dordrecht, pp. $425-431$.

Dabney, S. M., J. A. Delgado and D. W. Reeves (2001) Using winter cover crops to improve soil and water quality. Commun. Soil Sci. Plant Anal. 32: 1221-1250.

de Moraes, G. J., J. A. McMurtry, H. A. Denmark and C. B. Campos (2004) A revised catalog of the mite family Phytoseiidae. Zootaxa 434: 1-494.

Ehara, S. and T. Gotoh (eds.) (2009) Colored Guide to the Plant Mites of Japan. Zenkoku Noson Kyoiku Kyokai, Tokyo. 349 pp. (in Japanese).

Gerson, U., R. L. Smiley and R. Ochoa (2003) Mites (Acari) for Pest Control. Blackwell Science, Oxford. 539 pp.

Gotoh, T., T. Akizawa, M. Watanabe, A. Tsuchiya and S. Shimazaki (2005) Cold hardiness of Neoseiulus californicus and N. womersleyi (Acari: Phytoseiidae). J. Acarol. Soc. Jpn. 14: 93-103.

Hart, A. J., J. S. Bale, A. G. Tullett, M. R. Worland and K. F. A. Walters (2002) Effects of temperature on the establishment potential of the predatory mite Amblyseius californicus McGregor (Acari: Phytoseiidae) in the UK. J. Insect Physiol. 48: 593-599.

Jolly, R. L. (2000) The predatory mite Neoseiulus californicus: its potential as a biocontrol agent for the fruit tree red spider mite Panonychus ulmi in the UK. Proc. 2000 Brighton Conf.-Pests and Diseases 1: 487-490.

Jung, C. and J.-H. Lee (2004) Phytoseiid mites (Acari: Phytoseiidae) of pear orchards from Cheonan area in Korea. Korean J. Soil Zool. 9: 24-28 (in Korean with English summary).

Jung, C., S. Kim, S. W. Lee and J.-H. Lee (2003) Phytoseiid mites (Acari: Phytoseiidae) from Korean apple orchards and their ecological notes. Kor. J. Appl. Entomol. 42: 185-195 (in Korean with English summary).

Jung, C., D. H. Kim and M. O. Ryu (2006) A new finding of the predatory mite, Amblyseius californicus (Acari: Phytoseiidae) in Jeju, Korea. J. Asia-Pacific Entomol. 9: 321-325.

Katayama, H., S. Masui, M. Tsuchiya, A. Tatara, M. Doi, S. Kaneko and T. Saito (2006) Density suppression of the citrus red mite Panonychus citri (Acari: Tetranychidae) due to the occurrence of Neoseiulus californicus (McGregor) (Acari: Phytoseiidae) on Satsuma mandarin. Appl. Entomol. Zool. 41: 679-684.

Kawashima, M., B.-K. Chung and C. Jung (2008) Herbivorous and predacious mites on persimmon trees, Diospyros kaki Thunb., in Korea. Int. J. Acarol. 34: 167-174.

Kiritani, K. (2006) Predicting impacts of global warming on population dynamics and distribution of arthropods in Japan. Popul. Ecol. 48: 5-12.

Kishimoto, H., M. Teshiba, T. Kondoh, T. Miyazaki, N. Sugiura, S. Toda, R. Yamasaki, H. Wakatsuki, H. Motoyama and H. Horie (2007) Occurrence of Neoseiulus californicus (Acari: Phytoseiidae) on citrus in the Kyushu district, Japan. J. Acarol. Soc. Jpn. 16: 129-137 (in Japanese with English summary).

Landis, D. A., S. D. Wratten and G. M. Gurr (2000) Habitat management to conserve natural enemies of arthropod pests in agriculture. Annu. Rev. Entomol. 45: 175-201.

Leetham, J. W. and C. D. Jorgensen (1969) Overwintering 
phytoseiid mites in central Utah apple orchards. Great Basin Nat. 29: 96-104.

Mochizuki, M., T. Sasawaki, A. Mochizuki, K. Yara and N. Haruyama (2005) Species composition of phytoseiid mites in orchards after 13 years of exotic Typhlodromus occidentalis release. Ann. Rep. Kanto-Tosan Plant Prot. Soc. 52: 107-109 (in Japanese with English summary).

Morris, M. A., B. A. Croft and R. E. Berry (1996) Overwintering and effects of autumn habitat manipulation and carbofuran on Neoseiulus fallacis and Tetranychus urticae in peppermint. Exp. Appl. Acarol. 20: 249-258.

Nomikou, M., A. Janssen, R. Schraag and M. W. Sabelis (2002) Phytoseiid predators suppress populations of Bemisia tabaci on cucumber plants with alternative food. Exp. Appl. Acarol. 27: 57-68.

Nyrop, J. P., J. C. Minns and C. P. Herring (1994) Influence of ground cover on dynamics of Amblyseius fallacis Garman (Acarina; Phytoseiidae) in New York apple orchards. Agric. Ecosyst. Environ. 50: 61-72.

Ohnishi, R., S. Kanazaki, M. Aono, T. Sakimoto and Y. Ohmasa (2006) Studies on the usage of a natural enemy in the control of citrus red mite, Panonychus citri (McGregor) (No.2): effect of control in a satsuma mandarin orchard by Neoseiulus californicus (McGregor). Bull. Ehime Fruit Tree Exp. Sta. 20: 19-32 (in Japanese with English summary).

Ohtsuka, K. and Mh. Osakabe (2009) Deleterious effects of UV-B radiation on herbivorous spider mites: they can avoid it by remaining on lower leaf surfaces. Environ. Entomol. 38: 920-929.
Pringle, K. L. and J. M. Heunis (2006) Biological control of phytophagous mites in apple orchards in the Elgin area of South Africa using the predatory mite, Neoseiulus californicus (McGregor) (Mesostigmata: Phytoseiidae): a benefit-cost analysis. Afr. Entomol. 14: 113-121.

Raworth, D. A., G. Fauvel and P. Auger (1994) Location, reproduction and movement of Neoseiulus californicus (Acari: Phytoseiidae) during the autumn, winter and spring in orchards in the south of France. Exp. Appl. Acarol. 18: 593-602.

Ryu, M.-O. (1993) A review of the Phytoseiidae (Mesostigmata: Acarina) from Korea. Insecta Koreana 10: 92137.

Ryu, M.-O. (2007) List of and key to the genera and species of the subfamily Amblyseiinae (Acari: Phytoseiidae) in Korea. Entomol. Res. 37: 251-260.

Ryu, M. O., W. K. Lee and T. H. Kim (1997) Habitats and abundances of Korean phytoseiid mites. Kor. J. Appl. Entomol. 36: 224-230 (in Korean with English summary).

Ryu, M. O., W. K. Lee and S. R. Cho (2001) Phytoseiid mites (Acari: Phytoseiidae) from the pear field of Naju District in Korea. Korean J. Soil Zool. 6: 7-9.

Tougou, D., D. L. Musolin and K. Fujisaki (2009) Some like it hot! Rapid climate change promotes changes in distribution ranges of Nezara viridula and Nezara antennata in Japan. Entomol. Exp. Appl. 130: 249-258.

Veerman, A. (1992) Diapause in phytoseiid mites: a review. Exp. Appl. Acarol. 14: 1-60. 